\title{
MONITORING OF THE TOPMOUTH GUDGEON, PSEUDORASBORA PARVA (ACTINOPTERYGII: CYPRINIFORMES: CYPRINIDAE) IN A SMALL UPLAND CIEMIĘGA RIVER, POLAND
}

\author{
Jacek RECHULICZ* \\ Division of Hydrobiology, University of Life Sciences in Lublin, Poland
}

Rechulicz J. 2011. Monitoring of the topmouth gudgeon, Pseudorasbora parva (Actinopterygii: Cypriniformes: Cyprinidae) in a small upland Ciemięga River, Poland. Acta Ichthyol. Piscat. 41 (3): 193-199.

Background. The topmouth gudgeon, Pseudorasbora parva (Temminck et Schlegel, 1846) (known also as stone moroko), is an alien species of the fish fauna of many European freshwater ecosystems. In large quantities, its may affect negatively the fish fauna and the functioning of ecosystems. It competes for food with native fish species and they occupy their habitat. The knowledge about the invasion dynamics may help to find suitable control measures. The aim of this study was to find and observe the population of $P$. parva in a small river.

Materials and methods. Inventory fishing on three sampling sites at the Ciemięga River was carried out from 2003 to 2007. The abundance and density of $P$. parva in the river were calculated. The size distribution of $P$. parva and its length-weight relation were determined. Abundance, density, length, and mass of the fish from all study sites were analyzed statistically. Results. $P$. parva was first recorded in the Ciemięga River in the autumn of 2005. The abundance of $P$. parva in relation to the structure of the local ichthyofauna was the smallest in the spring and the highest in autumn. The total length of $P$. parva ranged from 15 to $104 \mathrm{~mm}$, and the mass from 0.2 to $10.4 \mathrm{~g}$. Taking into account the number of the specimens, $P$. parva constituted between $0.9 \%$ and $57.2 \%$ of the local ichthyofauna, while its mass ranged from $0.0 \%$ to $35.1 \%$ depending on the study site and the season. The density of $P$. parva ranged from 72.9 to $6.5 \mathrm{CPUE}_{\mathrm{N}}$, while the mean value for the river was $30.6 \mathrm{CPUE}_{\mathrm{N}}$.

Conclusion. In Polish waters $P$. parva is an alien species and there is still little information about its occurrence in the flowing waters. Since 2005, this species was present almost in all inventory catches in the Ciemięga River. Its presence was dependent on the kind of the habitat and the presence of predatory fish species (eg brown trout). $P$. parva occurring numerous may be a lot of competition for native fish species, and therefore an important problem is to understand his habitat preferences and interactions with native fish species.

Keywords: topmouth gudgeon, stone moroko, Pseudorasbora parva, invasive species, alien species, density, biomass, small river

\section{INTRODUCTION}

The topmouth gudgeon, Pseudorasbora parva (Temminck et Schlegel, 1846) (known also as stone moroko), is a small cyprinid species native to Japan, China, Korea, and the Amur River basin, and it is a highly invasive fish species in Europe (Caiola and De Sostoa 2002, Pinder et al. 2005, Ekmekçi and Kirankaya 2006).

The species was introduced probably with stocking material of herbivorous fish, such as: grass carp, Ctenopharyngodon idella (Valenciennes, 1844); bighead carp, Hypophthalmichthys nobilis (Richardson, 1845); and silver carp, H. molitrix (Valenciennes, 1844) imported from China and it has spread in the last 40 years through almost the entire continent of Europe (Witkowski 1991a, b, 2006, Rosecchi et al. 2001, Gozlan et al. 2002, Copp et al. 2005, Pollux and Körösi 2006).
The invasion success of $P$. parva can be explained by several of its biological attributes: physiological tolerance, short generation time, high reproductive potential, feeding flexibility, and parental care (Adámek and Siddiqui 1997, Katano and Maekawa 1997, Rosecchi et al. 2001, Pollux et al. 2006).

Research issues concerning $P$. parva are mainly focused on the first records of this species in different regions of Europe (Wildekamp et al. 1997, Caiola and De Sostoa 2002, Pinder et al. 2005, Ekmekçi and Kirankaya 2006) as well as its morphometry, biology, behaviour, age, and growth (Sunardi at al. 2005, 2007, Kapusta et al. 2008, Záhorská et al. 2009, 2010). In recent years, a few papers concerning the impact of predatory fish on $P$. parva and the possibility of eradicating this species from freshwater ecosystems have appeared

\footnotetext{
* Correspondence: Dr Jacek Rechulicz, Pracownia Rybactwa, Katedra Hydrobiologii, Uniwersytet Przyrodniczy w Lublinie, ul. Dobrzańskiego 37, 20-262 Lublin, Poland, phone: (+48) 81-461-0061 ext. 309, mobile (+48) 608518195, e-mail: jacek.rechulicz@up.lublin.pl.
} 
(Brazier and Britton 2006, Musil and Adámek 2007, Britton et al. 2008).

In Poland P. parva was recorded for the first time as late as 1990; it got here with stocking material of carp, and in recent years has spread to almost all lowland rivers of the country (Witkowski 1991a, b, 2002).

The aim of the presently reported study was to find and observe the population of topmouth gudgeon, $P$. parva, in a small river in south-eastern Poland. The monitoring of populations of $P$. parva in a small upland river may be a unique opportunity for determining, over a period of several years, the share of these species in the ichthyofauna of the watercourse, and may be a contribution to better understanding of the ecology of this species and its impact on water ecosystems.

\section{MATERIAL AND METHODS}

The research area was the Ciemięga River located in south-eastern Poland. This river is $36 \mathrm{~km}$ long and a part of its course is considered a mountain-type river, a trout and grayling zone. The catchment area of the Ciemięga River covers $157 \mathrm{~km}^{2}$ and the average water flow amounts to $0.58 \mathrm{~m}^{3} \cdot \mathrm{s}^{-1}$ (Michalczyk et al. 1997, Gliński and Stępniewska 2005). In 1990, the Ciemięga Valley Landscape Protection Area was created in the valley of Ciemięga.

Three 100-m long sampling sites (located in the vicinity of villages: Jastków (S1), Dys (S2), and Pliszczyn (S3) were defined on the Ciemięga River:

S1 (Jastków): bottom covered by sand and gravel, many submerged macrophytes; river bed straight; low, flat embankment; bank vegetation dominated by stinging nettle, Urtica dioica L., and white deadnettle, Lamium album L.; few trees; some sections of the river regulated.

S2 (Dys): bottom covered by sand and gravel with occasional mud, many submerged macrophytes; river bed irregular with small meanders, high and steep embankment; bank vegetation dominated by stinging nettle, Urtica dioica L., and white deadnettle, Lamium album L.; few trees; some sections of the river regulated; near the bridge the embankment with concrete blocks.

S3 (Pliszczyn): bottom covered by gravel and sand, few macrophytes; river shallow, river bed straight, flat banks, elevated valley slopes; banks with trees: black alder, Alnus glutinosa L., and white willow, Salix alba L.; river natural, without modifications, a weir above the study site.

Other characteristics of the sampling sites are presented in Table 1. Between the second and the third study sites (S2 and S3), above the village Pliszczyn, there is a severalmeter-high weir, preventing the upstream fish migration.

Inventory fishing on all study sites was conducted ten times in total: autumn 2003, autumn 2004, spring and autumn 2005, and spring, summer, and autumn 2006 and 2007. The fish were caught using electrofishing device IUP-12 (220-250V, 7A) across the whole width of the river bed, and wading up the river (Hickley 1990). Before the inventory fishing, each of the sections from both sites (upper and lower) was separated by a net barrier of 8-mm mesh size.
The fish collected were identified to the species level and weighed ( $W$; to nearest $0.1 \mathrm{~g}$ ); total length (TL) and standard length (SL) were measured (to nearest $1 \mathrm{~mm}$ ). Native fish specimens were put back into the water. The specimens of topmouth gudgeon were killed with an overdose of 2-phenoxyethanol, followed by immediate preservation in $4 \%$ formaldehyde.

The density of P. parva was estimated as catch per unit effort, which was related either to the number$\left(\mathrm{CPUE}_{\mathrm{N}}\right)$ or to the biomass $\left(\mathrm{CPUE}_{\mathrm{B}}\right)$ of fish caught within a $100-\mathrm{m}$ stretch of the river during $1 \mathrm{~h}$ of fishing (Anonymous 2008). Those parameters were convenient for comparison of the fish abundance and the abundance of topmouth gudgeon on all study sites. At each sampling site and at all sampling dates the abundance $P$. parva in terms of the number and in terms of the biomass of the ichthyofauna were determined. The frequency of topmouth gudgeon TL was determined using the Kolmogorov-Smirnov test and fitted for log-normal distribution. Length-weight relations were developed by regression of $\log W[\mathrm{~g}]$ against $\log$ TL $[\mathrm{mm}]$ for each specimen, producing values for the parameters $a$ and $b$ in the length-weight equation: $W=a \mathrm{TL}^{b}$. where: $W=$ body mass $[\mathrm{g}], \mathrm{TL}=$ total length $[\mathrm{mm}], a$ and $b=$ parameters describing linear regression (Schneider et al. 2000).

The statistical significance of the differences between topmouth gudgeon abundance, density, TL, and body mass of fish from all study sites was evaluated by non- parametrical ANOVA at the level $P \leq 0.05$ (Anonymous 2001).

The presently reported study has been carried out in accordance with Polish regulations on experiments on animals.

\section{RESULTS}

A total of 2633 specimens representing 15 species and 7 families were collected from 2003 to 2007 . The first presence of topmouth gudgeon in the Ciemiegga River was noted in summer 2005. This species was recorded only on site S1 in Jastków (Fig. 1). The topmouth gudgeon was also present in all subsequent catches at sites $\mathrm{S} 1$ and $\mathrm{S} 2$. The lowest number of $P$. parva specimens was caught on site S3, where its presence was noted only in spring and summer 2006 and in summer 2007 (Fig. 1). The presence and the share of P. parva in the overall fish abundance and the total number of fish caught in the Ciemięga River is shown in Fig. 1.

The contribution of this species was variable depending on the study site (with no statistical differences) and ranged from $0.9 \%$ to $57.2 \%$ on site $\mathrm{S} 1$. The share of $P$. parva in the catches on site $\mathrm{S} 2$ was from $1.7 \%$ to $22.9 \%$, while on site $\mathrm{S} 3$, if it was present, it had a share from $3.4 \%$ to $27.0 \%$ (Fig. 1 ).

A certain seasonal trend was observed, especially in the case of site $\mathrm{S} 1$, where the presence of $P$. parva increased in the successive seasons, the smallest participation of the species being noted in spring and the highest in autumn (Fig. 1). In total, topmouth gudgeon participation in the fish biomass of the Ciemięga River was low and ranged from 0.0 to $35.1 \%$, with the largest abundance on site $\mathrm{S} 1$ (Table 2). 
Overall density of the species ranged from 2.4 to 324 $\mathrm{CPUE}_{\mathrm{N}}$ depending on the season and the study site, and the differences, though notable, were not statistically significant (Table 2). The highest average density of $P$. parva was recorded in site $\mathrm{S} 1$, where 73 specimens of this species were caught, and the lowest-more than ten times smaller-on site S3 (6.5 $\left.\mathrm{CPUE}_{\mathrm{N}}\right)$.

The biomass density of $P$. parva on sites S2 and S3 was similar and ranged from 24 to $25 \mathrm{CPUE}_{\mathrm{B}}$, and the highest $\mathrm{CPUE}_{\mathrm{B}}$ was recorded on site $\mathrm{S} 1\left(\mathrm{CPUE}_{\mathrm{B}}=162\right)$, with significant statistical differences (ANOVA, $F=9.98$, $P=0.0371$ ) (Table 2).

The TL of topmouth gudgeon ranged from $15 \mathrm{~mm}$ to $104 \mathrm{~mm}$. The mass of the fish varied from 0.2 to $10.40 \mathrm{~g}$ (Table 3). The highest average length and average body mass were recorded for $P$. parva from site S3 (Table 3), and they proved to be significantly higher then for fish from S1 and S2 (TL: ANOVA, $F=9.64, P=0.0001$; $W$ : ANOVA, $F=15.05, P<0.0001)$. The smallest average total length was noted for $P$. parva from site $\mathrm{S} 2$.

The Kolmogorov-Smirnov test showed that the distribution of total length of topmouth gudgeon in the Ciemięga River corresponds to the log-normal distribution (KS test, $D=0.999, P<0.01$ ). The largest numbers of individuals were noted within the body length range from 50 to $60 \mathrm{~mm}$. The relation between total length (TL) and body mass $(W)$ was described with an exponential regression curve and it is represented by the equation $W=0.032 \mathrm{TL}^{2.245}\left(R^{2}=0.6728\right)($ Fig. 2).

\section{DISCUSSION}

The presence of Pseudorasbora parva was noted in stagnant and running waters of many countries in Europe, and in the Polish waters it appeared as late as in the early 1990s (Witkowski 1991a, b). The routes of spread of this species are diverse, but in most cases the fish gets into new ecosystems along with fish fry of such species as e.g., Ctenopharyngodon idella, Hypophthalmichthys nobilis, or H. molitrix) (see Ekmekçi and Kirankaya 2006, Witkowski 2006).

According to Witkowski (2006), P. parva is a species occurring in large numbers in fish breeding ponds, but Kapusta et al. (2008) also noted it in the Konin Reservoir and in artificially heated Licheńskie Lake. Despite such abundance of this species in the inland waters there are only few studies on its occurrence on the Polish territory.

In the Ciemięga River this species was first recorded in summer 2005, where it probably migrated from nearby ponds located in the river valley. Especially in the valley of the upper river there are many of the pond-type small reservoirs used for amateur fish farming.

It is probable that topmouth gudgeon could migrate with other fish from those ponds into the river itself. Earlier inventory fishing conducted in the years from 2003 through 2005 did not reveal the presence of this species.

Morphological characteristics and water physical and chemical parameters on sampling site

Table 1 of River Ciemięga (after Rechulicz 2010, altered)

\begin{tabular}{lccc}
\hline Parameter* & \multicolumn{3}{c}{ Sampling site } \\
\cline { 2 - 4 } & $\mathrm{S} 1$ (Jastków) & S2 (Dys) & S3 (Pliszczyn) \\
\hline GPS coordinates & $51^{\circ} 18^{\prime} 36^{\prime \prime} \mathrm{N}$ & $51^{\circ} 18^{\prime} 49^{\prime \prime} \mathrm{N}$ & $21^{\circ} 18^{\prime} 08^{\prime \prime} \mathrm{N}$ \\
Distance from river source $[\mathrm{km}]$ & $22^{\circ} 26^{\prime} 00^{\prime \prime} \mathrm{E}$ & $22^{\circ} 33^{\prime} 52^{\prime \prime} \mathrm{E}$ & 33 \\
Width of the river bed $[\mathrm{m}]$ & 18 & 26 & $4.50-6.00$ \\
River depth $[\mathrm{m}]$ & $2.50-3.00$ & $3.50-4.00$ & $0.30-0.45$ \\
Water pH & $0.30-0.60$ & $0.40-0.90$ & 7.60 \\
Water conductivity $\left[\mu \mathrm{S} \cdot \mathrm{mL}^{-1}\right]$ & 7.71 & 7.76 & 556.11 \\
Water temperature $\left[{ }^{\circ} \mathrm{C}\right]$ & 582.34 & 628.11 & 9.23 \\
Oxygen saturation $[\%]$ & 9.35 & 9.40 & 93.91 \\
Dissolved oxygen $\left(\mathrm{mg} \cdot \mathrm{L}^{-3}\right)$ & 90.30 & 89.02 & 10.69 \\
\hline
\end{tabular}

*mean values for three seasons of 2007 (spring, summer, and autumn).

Share of biomass, number-, and biomass density of Pseudorasbora parva in the ichthyofauna

Table 2 of the Ciemięga River

\begin{tabular}{lccccccccc}
\hline \multirow{2}{*}{ Site } & \multicolumn{3}{c}{ W\% } & \multicolumn{3}{c}{ CPUE $_{\mathrm{N}}$} & \multicolumn{3}{c}{ CPUE $_{\mathrm{B}}$} \\
\cline { 2 - 10 } & Range & Mean & \multicolumn{1}{c}{ SD } & Range & Mean & SD & Range & Mean & SD \\
\hline S1 (Jastków) & $2.20-35.10$ & 11.58 & 11.51 & $2.40-324.00$ & $72.90^{\mathrm{A}}$ & 113.59 & $12.00-505.00$ & 162.51 & 176.54 \\
S2 (Dys) & $0-5.70$ & 1.50 & 2.08 & $0-40.80$ & $12.60^{\mathrm{B}}$ & 15.56 & $0-69.60$ & 25.22 & 31.01 \\
S3 (Pliszczyn) & $0-3.90$ & 0.91 & 1.52 & $0-27.30$ & $6.50^{\mathrm{B}}$ & 10.12 & $0-90.00$ & 24.43 & 34.99 \\
Total & $0-35.10$ & 4.70 & 8.18 & $0-324.00$ & 30.60 & 70.13 & $0-505.00$ & 70.70 & 120.12 \\
\hline
\end{tabular}

$W \%=$ share of biomass; $\mathrm{SD}=$ standard deviation; $\mathrm{CPUE}_{N}=$ catch (No.) per unit effort [number of fish caught on 100-m stretch of the river within 1 hour]; $\mathrm{CPUE}_{B}=$ catch (mass) per unit effort [biomass of fish caught on 100-m stretch of the river within 1 hour]; Figures in the same column with the same superscript are not significantly different $(P>0.05)$. 
It is possible that in the years to come this species will spread throughout the main river system of the Bystrzyca River. Single individuals of the species were recorded by Rechulicz (2009) within 2006-2007 in the Czerniejówka River, also a left-bank tributary of the Bystrzyca River.

The number of $P$. parva varied seasonally, usually it was the lowest in the spring and the highest in the autumn (Fig. 1). It is possible that much higher numbers of topmouth gudgeon in autumn (especially on the site S1) could be the result of escapes from ponds, being often drained in autumn. However, this species was found in each season at S1 and S2, and its higher abundance has also been reported in summer on $\mathrm{S} 2$, without any ponds in the proximity. This might indicate a possible relation between the numbers of topmouth gudgeon and the growth intensity of submerged macrophytes. This was especially evident on site S1, where the macrophytes were much more abundant (Table 1). The regularity of changes in the number of $P$. parva depending on the coverage of shallow littoral lake by macrophytes was also observed by Pollux and Körösi (2006) and Kapusta et al. (2008). Those authors found that in places with greater vegetation cover, this species appeared in larger numbers. More abundant submerged macrophytes provide a better refuge from predators for $P$. parva and at the same time makes it harder to catch (Sunardi et al. 2005). Several studies indicated that this species can be eaten by predatory fish species and may even constitute the basis of their diet (Musil and Adámek 2007). However, as reported by Kapusta et al. (2008), in spite of the significant proportion of predatory species in the ichthyofauna of artificially heated Licheńskie Lake, they had no effect on the abundance of this invasive species.

Noteworthy is the fact that in the current studies topmouth gudgeon was less numerous on site S3, located in the vicinity of Pliszczyn. The Ciemięga River in this
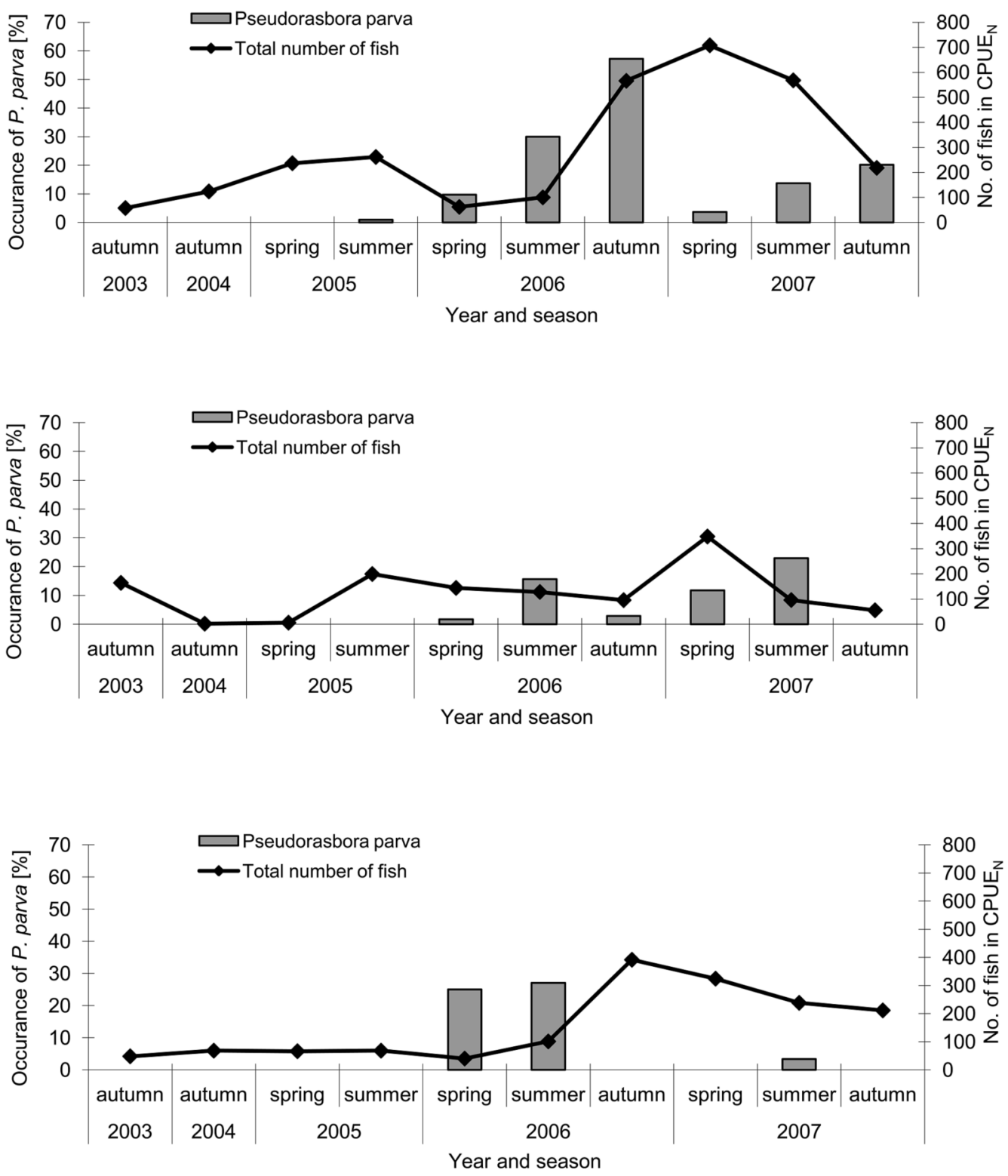

Fig. 1. Occurrence of Pseudorasbora parva at sampling sites S1, S2, and S3 in the Ciemięga River within 2003-2007 
stretch is more like a mountain river and the fish structure is dominated by salmonid species, such as the brown trout, Salmo trutta L. It is possible that, due to the specific character of the river at this site, $P$. parva was the only food item available for the trout. The latter fish, being numerous on site S3 was able to control effectively the numbers of the topmouth gudgeon (Rechulicz 2010). The above assumption can be supported by the present results, showing that the highest numbers and the density of topmouth gudgeon were found on site S1 (Table 2).

The density of topmouth gudgeon depends on the type of water. As reported by Pollux and Körösi (2006), in floodplain lakes it was substantially more abundant than in the rivers of the Netherlands $\left(0.11\right.$ ind. $\cdot \mathrm{m}^{-2}$ and 141 ind. $\cdot \mathrm{m}^{-2}$, respectively). Similarly, small numbers of this species, on average $6.1 \cdot \mathrm{m}^{-2}$, were noted by Britton et al. (2007) in the North West of the UK. Large quantities of it were recorded also in ponds in southern Czech Republic (from 370 to 14331 ind. $\cdot \mathrm{ha}^{-1}$ ) (Adámek and Sukop 2000) and in ponds in Poland (ca. $300 \mathrm{~kg}$ of $P$. parva from a pond of ca. 5 ha) (Witkowski 2006). Much less P. parva, on average only $0.65 \mathrm{~m}^{-2}$, was caught in the Ciemięga River at site $\mathrm{S} 1$ (Table 2, after conversion to $\mathrm{m}^{2}$ at $2.5 \mathrm{~m}$ average width of the riverbed in that place). This gave a density comparable to that estimated by Pollux and Körösi (2006).

Analysis of distribution of total length of the studied fish suggests that the population of $P$. parva from the Ciemięga River included individuals representing all stages from juveniles to sexually mature ones. Individuals measuring from 50 to $60 \mathrm{~mm}$ (TL) were characterised by the highest frequency and, as reported by Záhorská et al. (2010), were sexually mature. It is worth to emphasize that in the presently reported study, specimens longer than $10 \mathrm{~cm}$ were also caught - the size rarely reported by other authors (Britton et al. 2007, 2008, Kapusta et al. 2008, Záhorská et al. 2010). This may indicate the presence in the population of old sexually mature $P$. parva, capable of intensive spawning at suitable habitat conditions

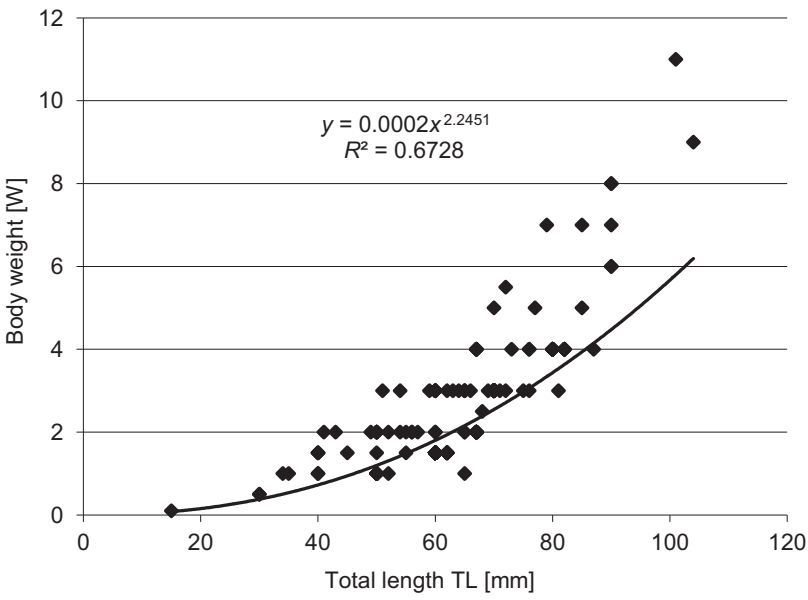

Fig. 2. Length-weight relations of Pseudorasbora parva from the Ciemięga River within 2003-2007

(Záhorská and Kováč 2009). The effectiveness of spawning, in the Ciemięga River, can also be confirmed by the capturing $P$. parva individuals of minimal length of $15 \mathrm{~mm}$ (TL) (Table 3).

Topmouth gudgeon, as an alien species, can spread and may have an impact on other species present in the river system. High density and no effect of predators on its population may lead to the spreading of diseases, increased competitiveness for food and habitat space, particularly in relation to native fish species such as gudgeon, sunbleak, and roach (Pinder et al. 2005, Gozlan and Beyer 2006, Britton et al. 2007, Carpentier et al. 2007).

In summary, the understanding of the population dynamics and of the occurrence of $P$. parva in small rivers can affect the search for possible ways of inhibiting the spreading of this species throughout river systems and contribute to reducing its numbers. The issue that needs clarification are contradictory conclusions about the effect of predatory fish on topmouth gudgeon. As reported by Kapusta et al. (2008), predators do not affect the population

Total length, standard length, and body mass of Pseudorasbora parva

Table 3 from the Ciemięga River sampled within 2005-2007

\begin{tabular}{lccccc}
\hline \multirow{2}{*}{ Feature } & & \multicolumn{3}{c}{ Sampling site } & Total \\
\cline { 2 - 5 } & & S1 (Jastków) & S2 (Dys) & S3 (Pliszczyn) & 316 \\
\cline { 2 - 5 } & Mean \pm SD & $62.50^{\mathrm{B}} \pm 0.90$ & $57.80^{\mathrm{C}} \pm 1.33$ & $69.90^{\mathrm{A}} \pm 1.39$ & $62.40 \pm 1.03$ \\
Total length [mm] & Range & $15.00-104.00$ & $34.00-90.00$ & $43.00-90.00$ & $15.00-104.00$ \\
& SE & 0.06 & 0.21 & 0.32 & 0.06 \\
Standard length $[\mathrm{mm}]$ & Rean $\pm \mathrm{SD}$ & $52.50^{\mathrm{B}} \pm 0.84$ & $47.00^{\mathrm{C}} \pm 1.13$ & $58.20^{\mathrm{A}} \pm 1.18$ & $52.10 \pm 0.93$ \\
& Range & $10.00-87.00$ & $29.00-75.00$ & $35.00-75.00$ & $10.00-87.00$ \\
& SE & 0.05 & 0.18 & 0.27 & 0.05 \\
Body mass $[\mathrm{g}]$ & Mean $\pm \mathrm{SD}$ & $2.23^{\mathrm{B}} \pm 1.86$ & $2.04^{\mathrm{B}} \pm 1.77$ & $3.87^{\mathrm{A}} \pm 1.63$ & $2.30 \pm 1.88$ \\
& Range & $0.20-10.40$ & $1.00-8.00$ & $1.00-8.00$ & $0.20-10.40$ \\
\hline
\end{tabular}

$n=$ number of fish; $\mathrm{SD}=$ standard deviation, $\mathrm{SE}=$ standard error of the mean; Figures in the same row with the same superscript are not significantly different $(P>0.05)$. 
of P. parva. According to Musil and Adámek 2007, however, this species can be the basis of predators' diet. If so, the effect of predators would be evident. It must be emphasized, however, that the spreading of $P$. parva, with all its characteristic features of an invasive species, can have a significant impact on populations of native fish species.

\section{ACKNOWLEDGEMENTS}

The author would like to thank Piotr Mazurek, Rafał Kostelecki, Maciej Woźny and Tomasz Pawluk for helpful assistance in the field work.

\section{REFERENCES}

Adámek Z. Siddiqui M.A. 1997. Reproduction parameters in a natural population of topmouth gudgeon, Pseudorasbora parva, and its condition and food characteristics with respect to sex dissimilarities. Polish Archives of Hydrobiology 44: 145-152.

Adámek Z., Sukop I. 2000. Vliv střevličky východni (Pseudorasbora parva) na parametry rybničniho prostředi. [Influence of stone moroko (Pseudorasbora parva) on the parameters of the pond environment.] Biodiverzita ichtiofauny České republiky 3: 37-43. [In Czech.]

Anonymous 2008. Glossary of statistical terms. OECD http://stats.oecd.org/glossary (accessed on 10 January 2011).

Anonymous 2001. SAS Users Guide. Version 8.2 Edn. SAS Institute Inc.

Brazier M., Britton J.R. 2006. Eradicating the invasive topmouth gudgeon, Pseudorasbora parva, from a recreational fishery in northern England. Fisheries Management and Ecology 13 (5): 329-335. DOI: 10.1111/j.1365-2400.2006.00510.x

Britton J.R., Davies G.D., Brazier M., Pinder A.C. 2007. A case study on the population ecology of a topmouth gudgeon (Pseudorasbora parva) population in the UK and the implications for native fish communities. Aquatic Conservation: Marine and Freshwater Ecosystems 17 (7): 749-759. DOI: 10.1002/aqc.809

Britton J.R., Brazier M., Davies G.D., Chare S.I. 2008. Case studies on eradicating the Asiatic cyprinid Pseudorasbora parva from fishing lakes in England to prevent their riverine dispersal. Aquatic Conservation: Marine and Freshwater Ecosystems 18 (6): 867-876. DOI: 10.1002/aqc.919

Caiola N., De Sostoa A. 2002. First record of the Asiatic cyprinid Pseudorasbora parva in the Iberian Peninsula. Journal of Fish Biology 61 (4): 1058-1060.

DOI: $10.1006 /$ jfbi.2002.2103.

Carpentier A., Gozlan R.E., Cucherousset J., Paillisson J.M., Marion L. 2007. Is topmouth gudgeon Pseudorasbora parva responsible for the decline in sunbleak Leucaspius delineatus populations? Journal of Fish Biology 71: 274-278. DOI: 10.1111/j.1095-8649.2007.01671.x

Copp G.H., Bianco P.G., Bogutskaya N., Erös T., Falka I., Ferreira M.T., Fox M.G., Freyhof J., Gozlan R.E., Grabowska J., Kováč V., Moreno-Amich R., Naseka A. M., Peňáz M., Povž M., Przybylski M., Robillard M., Russell I.C., Stakenas S., Šumer S., Vila-Gispert A., Wiesner C. 2005. To be, or not to be, a non-native freshwater fish? Journal of Applied Ichthyology 21: 242-262.

DOI: 10.1111/j.1439-0426.2005.00690.x
Ekmekçi F.G., Kirankaya S.G. 2006. Distribution of invasive fish species, Pseudorasbora parva (Temminck \& Schlegel, 1846) in Turkey. Turkish Journal of Zoology 30 (3): 329-334.

Gliński P., Stępniewska Z. 2005. Właściwości oksydoredukcyjne erodowanych gleb lessowych w dolinie Ciemięgi. [Oxydoreduction properties of eroded loess soils in Ciemięga catchment.] Acta Agrophysica 5 (3): 625-635. [In Polish.]

Gozlan R.E., Beyer K. 2006. Hybridisation between Pseudorasbora parva and Leucaspius delineatus. Folia Zoologica 55 (1): 53-60.

Gozlan R.E., Pinder A.C., Shelley J. 2002. Occurrence of the Asiatic cyprinid Pseudorasbora parva in England. Journal of Fish Biology 61 (1): 298-300. DOI: 10.1006/jfbi.2002.2042

Hickley P. 1990. Electric fishing in practice. Pp. 176-187. In: Cowx I.G., Lamarque P. (eds.) Fishing with electricityApplications in freshwater fisheries management. Oxford, Fishing News Books. Blackwell Scientific Publications, Oxford, UK.

Kapusta A., Bogacka-Kapusta E., Czarnecki B. 2008. The significance of stone moroko, Pseudorasbora parva (Temminck and Schlegel), in the small-sized fish assemblages in the littoral zone of the heated Lake Licheńskie. Archives of Polish Fisheries 16 (1): 49-62.

DOI: $10.2478 / \mathrm{s} 10086-008-0004-6$

Katano O., Maekawa K. 1997. Reproductive regulation in the female Japanese minnow, Pseudorasbora parva (Cyprinidae). Environmental Biology of Fishes 49 (2): 197-205. DOI: 10.1023/A:1007314817526

Michalczyk Z., Chmiel S., Głowacki S., Zielińska B. 1997. Ocena zasobów wodnych dorzecza Ciemięgi. Efekty proekologicznego zagospodarowania zlewni rzeki Ciemięgi. [Evaluation of water resources of Ciemięga River basin. Ecological effects of management of Ciemięga river basin.] Pp 21 - 36. In: Materiały konferencyjne IMiBR AR, Lublin. [In Polish.]

Musil J., Adámek Z. 2007. Piscivorous fishes diet dominated by the Asian cyprinid invader, topmouth gudgeon (Pseudorasbora parva). Biologia, Bratislava 62 (4): 488-490. DOI: 10.2478/s11756-007-0093-5

Pinder A.C., Gozlan R.E, Britton J.R. 2005. Dispersal of the invasive topmouth gudgeon Pseudorasbora parva in the UK: a vector for an emergent infectious disease. Fisheries Management and Ecology 12 (6): 411-414. DOI: $10.1111 / \mathrm{j} .1365-2400.2005 .00466 . x$

Pollux B.J.A., Körösi A. 2006. On the occurrence of the Asiatic cyprinid Pseudorasbora parva in the Netherlands. Journal of Fish Biology 69 (5): 1575-1580. DOI: $10.1111 /$ j.1095-8649.2006.01218.x

Pollux B.J.A., Körösi A., Verberk W.C.E.P., Pollux P.M.J. Van der Velde G. 2006. Reproduction, growth, and migration of fishes in a regulated lowland tributary: potential recruitment to the River Meuse. Hydrobiologia 565 (1): 105-120. DOI: 10.1007/s10750-005-1908-4

Rechulicz J. 2009. Ichthyofauna of small rivers of Lublin city. Teka Komisji Ochrony i Kształtowania Środowiska Przyrodniczego, OL PAN 6: 252-260. 
Rechulicz J. 2010. Size structure and body condition of brown trout (Salmo trutta trutta m. fario L.) from mountain type river in Lubelskie Upland. Teka Komisji Ochrony i Kształtowania Środowiska Przyrodniczego, OL PAN 7: 335-344.

Rosecchi E., Thomas F., Crivelli A.J. 2001. Can life-history traits predict the fate of introduced species? A case study on two cyprinid fish in southern France. Freshwater Biology 46 (6): 845-853. DOI: 10.1046/j.1365-2427.2001.00715.x

Schneider J.C., Laarman P.W., Gowing H. 2000. Length-weight relationships. Chapter 17. In: Schneider J.C. (ed.). Manual of fisheries survey methods II: with periodic updates. Michigan Department of Natural Resources, Fisheries Special Report 25, Ann Arbor.

Sunardi, Asaeda S.T., Manatunge J. 2005. Foraging of a small planktivore (Pseudorasbora parva: Cyprinidae) and its behavioral flexibility in an artificial stream. Hydrobiologia 549 (1): 155-166. DOI: 10.1007/s10750-005-5442-1

Sunardi, Asaeda T., Manatunge C.J. 2007. Physiological responses of topmouth gudgeon, Pseudorasbora parva, to predator cues and variation of current velocity. Aquatic Ecology 41 (1): 111-118. DOI: 10.1007/s10452-006-9048-0

Wildekamp R.H., Van Neer W., Küçük F., Ünlüsayin M. 1997. First record of the eastern Asiatic gobionid fish Pseudorasbora parva from the Asiatic part of Turkey. Journal of Fish Biology 51 (4): 858-861. DOI: 10.1111/j.1095-8649.1997.tb02006.x

Witkowski A. 1991a. Pseudorasbora parva (Schlegel, 1842) (Cyprinidae, Gobioninae) nowy gatunek w polskiej ichtiofaunie. [Pseudorasbora parva (Schlegel, 1842) (Cyprinidae,
Gobioninae) a new species to Polish ichthyofauna.] Przegląd Zoologiczny 35: 323-331. [In Polish.]

Witkowski A. 1991b. Czebaczek amurski (Pseudorasbora parva) - kolejny zawleczony gatunek w naszej ichtiofaunie. [Topmouth gudgeon (Pseudorasbora parva) - another introduced species in our ichthyofauna.] Komunikaty Rybackie 4: 23-25. [In Polish.]

Witkowski A. 2002. Introduction of fishes into Poland: benefaction or plague? Nature Conservation 59: 41-52.

Witkowski A. 2006. NOBANIS-Invasive Alien Species Fact Sheet-Pseudorasbora parva. In: Online Database of the North European and Baltic Network on Invasive Alien Species; NOBANIS www.nobanis.org (accessed on 10 Dec 2010).

Záhorská E., Kováč V. 2009. Reproductive parameters of invasive topmouth gudgeon Pseudorasbora parva (Temminck and Schlegel, 1846) from Slovakia. Journal of Applied Ichthyology 25 (4): 466-469. DOI: 10.1111/j.1439-0426.2009.01190.x

Záhorská E., Kováč V., Falka I., Beyer K., Katina S., Copp G.H., Gozlan R.E. 2009. Morphological variability of the Asiatic cyprinid, topmouth gudgeon Pseudorasbora parva, in its introduced European range. Journal of Fish Biology 74 (1): 167-185. DOI: 10.1111/j.1095-8649.2008.02121.x

Záhorská E., Kováč V., Katina S. 2010. Age and growth in a newly-established invasive population of topmouth gudgeon. Central European Journal of Biology 5 (2): 256-261. DOI: $10.2478 / \mathrm{s} 11535-010-0002-8$

Received: 21 April 2011

Accepted: 17 September 2011 Published electronically: 30 September 2011 